\title{
Investigation on Pyrolysis of Shivee-Ovoo Coal from Mongolia
}

\author{
B. Purevsuren ${ }^{\mathrm{a}^{*}}$, S. Batbileg ${ }^{\mathrm{b}}$, D. Batkhishig, A. Ankhtuya
}

Institute of Chemistry and Chemical Technology, MAS, Ulaanbaatar-51, Mongolia

abpurevsuren.icct@gmail.com, bbilegsanjaa@gmail.com

Keywords: Shivee-Ovoo coal, pyrolysis, hard residue, tar.

\begin{abstract}
Our present investigation on Shivee-Ovoo coal focused on characterization of the initial coal and its hard and liquid products after pyrolysis. First of all on the basis of proximate and ultimate analysis of Shivee-Ovoo coal have been confirmed that the Shivee-Ovoo coal is oxidized brown coal of lignite type with B2 mark. The thermal degradation process of Shivee-Ovoo coal was investigated by thermogravimetric analyzer and first time determined the thermal stability of the coal sample by determination of thermal indices such as $\mathrm{T}_{5 \%}-71.85^{\circ} \mathrm{C} ; \mathrm{T}_{15 \%}-321.18^{\circ} \mathrm{C} ; \mathrm{T}_{25 \%}-$ $490.64^{\circ} \mathrm{C}$ from the TG curve, which are the characteristics of lower thermal stability. The pyrolysis of Shivee-Ovoo coal carried out at different heating temperatures and determined the yields of obtained hard, liquid and gas products. A most suitable heating temperature was chosen $500^{\circ} \mathrm{C}$, in which the yield of condensed liquid product $-6.28 \%$ (tar) was higher. The yield of all liquid (tar and pyrolysis water) and gas products (44\%) shows that there was an intensive thermal decomposition of the coal organic mass with higher degree of conversion. This results also confirm the above mentioned and determined lower thermal stability characteristics of Shivee-Ovoo coal and it is more suitable for gasification and liquefaction. Also the yield of hard product (semicoke) is $56.48 \%$ at $500^{\circ} \mathrm{C}$, which is also important product of the pyrolysis of Shivee-Ovoo coal and it's proximate analysis results show that the volatile matter content decreased 3 times and increased caloric value by $1000 \mathrm{kcal}$ in comparison with the initial coal sample indicating that it can be used as a smokeless fuel. The determined chemical composition of pyrolysis tar in group organic compounds by chemical analysis show that the tar consists mostly neutral oils with highest content-81.9\%, asphalteines $-13.6 \%$, free carbons $-3.93 \%$ and organic bases, organic acids, phenolic compounds are less than $1.0 \%$. The tar also was distilled at room temperature and obtained several fractions with different boiling temperature ranges including yellow colored light fraction $-15.93 \%\left(18-180^{\circ} \mathrm{C}\right)$, brown colored middle fraction $-15.44 \%\left(180-330^{\circ} \mathrm{C}\right)$ and black colored heavy fraction $-44.53 \%$ $\left(330>{ }^{0} \mathrm{C}\right)$. The images of scanning electron microscopes (SEM) of prepared activated carbon from pyrolyzed hard residue in comparison with initial coal sample are different. The SEM image of initial coal sample has compact solid pieces. The SEM image of carbonized and activated coal sample shows a porosity structure with meso and macro pores in comparison with that of initial coal sample. The solubility and chemical composition of neutral oil isolated from the pyrolysis tar of Shivee-Ovoo coal investigated by GC/MS analysis and registered totally 68 peaks (signals) for the soluble in hexane , 100 peaks for the soluble in toluene and 100 peaks for the soluble in a mixed solvent of methylenchloride and methanol (1:1 volume ratio) fractions. Have been determined and identified 22 organic compounds soluble in hexane, 45 organic compounds soluble in toluene and 21 organic compounds soluble in a mixed solvent of methylenchloride and methanol fractions from each related totally registered peaks.
\end{abstract}

\section{Introduction}

Mongolia is among the 10 coal rich countries in the world with the 175 billion tones of geologically estimated coal resources including high quality bituminous coking coals, subbituminous coals and lignite brown coals. More than $70 \%$ of this coal resources belongs to the brown coals [1].

The Shivee-Ovoo brown coal deposit is one of the largest in the "Nyalga-Choir" coal bassin in the central economic region of Mongolia. It is very important to emphasize that the estimated coal resources is 2.7 billion tones and it is very near to the railway. The Shivee-Ovoo coal deposit 
has been worked as a open-cast mine since 1990 and is used in thermal power stations in Ulaanbaatar city. The Shivee-Ovoo coal deposit is located in the territory of the village "' Dalanjargalan" of the East-Gobi province $300 \mathrm{~km}$ southeast of Ulaanbaatar, Mongolia [2].

Results of our previous investigation on gasification of Shivee-Ovoo coal have shown that it is a reactive fuel under conditions that produce combustible gases, because of its high content of volatile matters $-42,57 \%$ [3]. Also the Shivee-Ovoo coal has been non-isothermally pyrolysed in a thermogravimetric analyser and in a fixed bed gasification reactor to determine the influence of heating temperature and heating rate on the thermal degradation of the coal sample [4].

\section{Experimental}

The analytical coal samples of Shivee-Ovoo deposit were prepared for analysis according to ASTM D 2797. The main technical characteristics such as proximate and ultimate analysis were performed according to Mongolian National Standards MNS 656-79 (moisture content), MNS 65279 (ash yield), MNS 654-79 (volatile matter yield), MNS 669-87 (gross calorific value) and MNS 895-79 (sulphur content).

For the determination of mineral content in Shivee-Ovoo coal have been obtained completely burned ashes of coals during slowly and continuously burning in furnace at $200-850{ }^{\circ} \mathrm{C}$. The content of mineral elements in coal samples and their oxides have been determined by using of X-ray fluorescence spectrometry.

The small-scale pyrolysis experiments of coal samples were performed in a laboratory quarts retort (tube) which could contain air dried and powdered to a particle size $<0,2 \mathrm{~mm} 1 \mathrm{~g}$ - of coal sample. The retort was placed in a horizontal electric tube furnace with a maximum heating temperature of $950^{\circ} \mathrm{C}$. A chrome-alumel thermocouple was immersed in the tube furnace to measure the actual heating temperature. The pyrolysis experiments have been carried out at different heating temperatures $200-700{ }^{\circ} \mathrm{C}$ with constant heating rate $20{ }^{\circ} \mathrm{C} / \mathrm{min}$. First of all the quarts retort with coal sample was heated for example to $600{ }^{\circ} \mathrm{C}$ with heating rate $20^{\circ} \mathrm{C} / \mathrm{min}$. and kept at $600{ }^{\circ} \mathrm{C}$ for $80 \mathrm{~min}$. The retort was connected with a thermostable glass tube heated also in a tube furnace at $80{ }^{\circ} \mathrm{C}$ for collecting of tars and this tube is also connected with a air-cooled glass vessel for collecting of pyrolysis water. The glass vessel for pyrolysis water is also connected with a thin glass tube for non-condensable gases. The yields of pyrolysis products including solid residue (coal char), tar (condensed liquid product) and pyrolysis water determined by weighing, and the yield of gases by differences.

The prepapative-scale pyrolysis experiments of coal sample was performed in a laboratory vertical cylindrical retort made by stainless steel which could contain $1000 \mathrm{~g}$. of sample. The retort was placed in an electric furnace (model SNOL) with a maximum temperature of $950^{\circ} \mathrm{C}$. A chromealumel thermocouple was immersed in the coal bed to measure the actual heating temperature and an equipment for temperature control (potentiometer). The retort was connected with a air-cooled iron tube and water-cooled laboratory glass condenser and a collection vessel for the condensed of liquid product (tar and pyrolysis water). The non-condensable gases after water-cooled condenser were left the system through a thin glass tube. The yields of products including hard residue (char), tar and pyrolysis water determined by weighing in \%, and the yield of gases by difference.

The liquid condensed by product of coal pyrolysis consists from tar and pyrolysis water. They form an unmixed two layers and can be separated easily by separating glass funnel. The upper layer is tar (viscous liquid) with black-brown color and unpleasant smell. The bottom layer is pyrolysis water (no viscous liquid) with bad smell and brown color. The final cleaning of tar from the pyrolysis water usually use thermally treated $\mathrm{CaCl}_{2}$ by mixing and separating (filtering or centrifuging).

The Fourier transform infrared spectroscopy (FTIR) spectra of the samples were obtained on a Interspec 200-X series of FTIR spectrometers with PIKE Diffusion IR accessories using a KBr disc containing $1 \%$ finely ground samples. All the spectra were measured in the frequency range of 4000 to $400 \mathrm{~cm}-1$, and 32 scans were taken per sample. 
First of all organic bases and organic acids were removed from the pyrolysis tar of ShiveeOvoo coal and so purified tar is called as a 'neutral oil',.

The column chromatography conditions neutral oil as follow:

- Small glass column: $5.0 \mathrm{ml}$

- Sample of tar 0.2g. for each solvent

- Used organic solvents (pure for chromatography): hexane, toluene and methylenchloride: methanol (1:1 mass ratio) $-20,0 \mathrm{ml}$ from each solvent.

- Used sorbent: activated silicagel $4.0 \mathrm{~g}$.

The column chromatography carried out for obtaining of the soluble in hexane $(\mathrm{H})$, toluene (T) and methylenechloride and methanol (M) fractions of the neutral oil. These fractions were used for GC/MS analysis.

The conditions of GC/MS analysis of each fractions are:

- The analytical sample of each fraction: 1 microliter of each fraction in $1 \mathrm{ml}$ of each solvent.

- The sample of GC/MS analysis: 1 microliter from each analytical sample.

- Used apparatus: Agilent 7890A Agilent 5975C GCMS system and capillary column J\&W

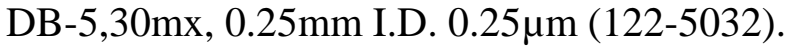

- Carrier gas: He

- Mass range: 50-550.

- Starting temperature of furnace: $100^{\circ} \mathrm{C}$.

- Heating temperature and time: $220^{\circ} \mathrm{C}, 46 \mathrm{~min}$.

\section{Results and Discussion}

The results of proximate and ultimate analysis of coal samples from Shivee-Ovoo deposit are shown in Table 1.

Table 1. Proximate and ultimate analyses of Shivee-Ovoo coal.

\begin{tabular}{|c|c|c|c|c|c|c|c|c|}
\hline Sample & \multicolumn{4}{|c|}{ Proximate analysis, \% } & \multicolumn{3}{|l|}{ Ultimate analysis, \% } \\
\cline { 2 - 8 } & $\begin{array}{c}\text { Moisture, } \\
\mathrm{W}^{\mathrm{a}}\end{array}$ & $\begin{array}{c}\text { Ash, } \\
\mathrm{A}^{\mathrm{d}}\end{array}$ & $\begin{array}{c}\text { Volatile } \\
\text { matter, } \\
\mathrm{V}^{\text {daf }}\end{array}$ & $\begin{array}{c}\text { Caloric } \\
\text { value, } \\
\mathrm{Q}^{\text {daf }} \\
\mathrm{kcal} / \mathrm{kg}\end{array}$ & $\begin{array}{l}\text { Carbon, } \\
\mathrm{C}^{\text {daf }}\end{array}$ & $\begin{array}{c}\text { Hydro- } \\
\text { gen, } \\
\mathrm{H}^{\text {daf }}\end{array}$ & $\begin{array}{c}\text { Sulfure } \\
\text { total, } \\
\mathrm{St}\end{array}$ & $\begin{array}{c}\text { Oxygen } \\
\text { and } \\
\text { others, } \\
(\mathrm{N}+\mathrm{O})^{\text {daf }}\end{array}$ \\
\hline $\begin{array}{c}\text { Shive- } \\
\text { Ovoo } \\
\text { coal }\end{array}$ & 13,41 & 21,17 & 42,57 & 6501,2 & 71,36 & 4,99 & 1,06 & 22,59 \\
\hline
\end{tabular}

The results of proximate and ultimate analysis in Table 1 for example the content of volatile matter, the ratio of $\mathrm{H} / \mathrm{C}=0.84$, carbon and oxygen content indicate that coal from Shivee-Ovoo deposit is a low rank B2 (ISO 11760) brown coal. The content of total sulfure is not higher and not so dangerous for the environment.

To characterize the organic matter of the Shivee-Ovoo coal has been analyzed by IR analysis and the IR spectra is shown in Fig. 1. 


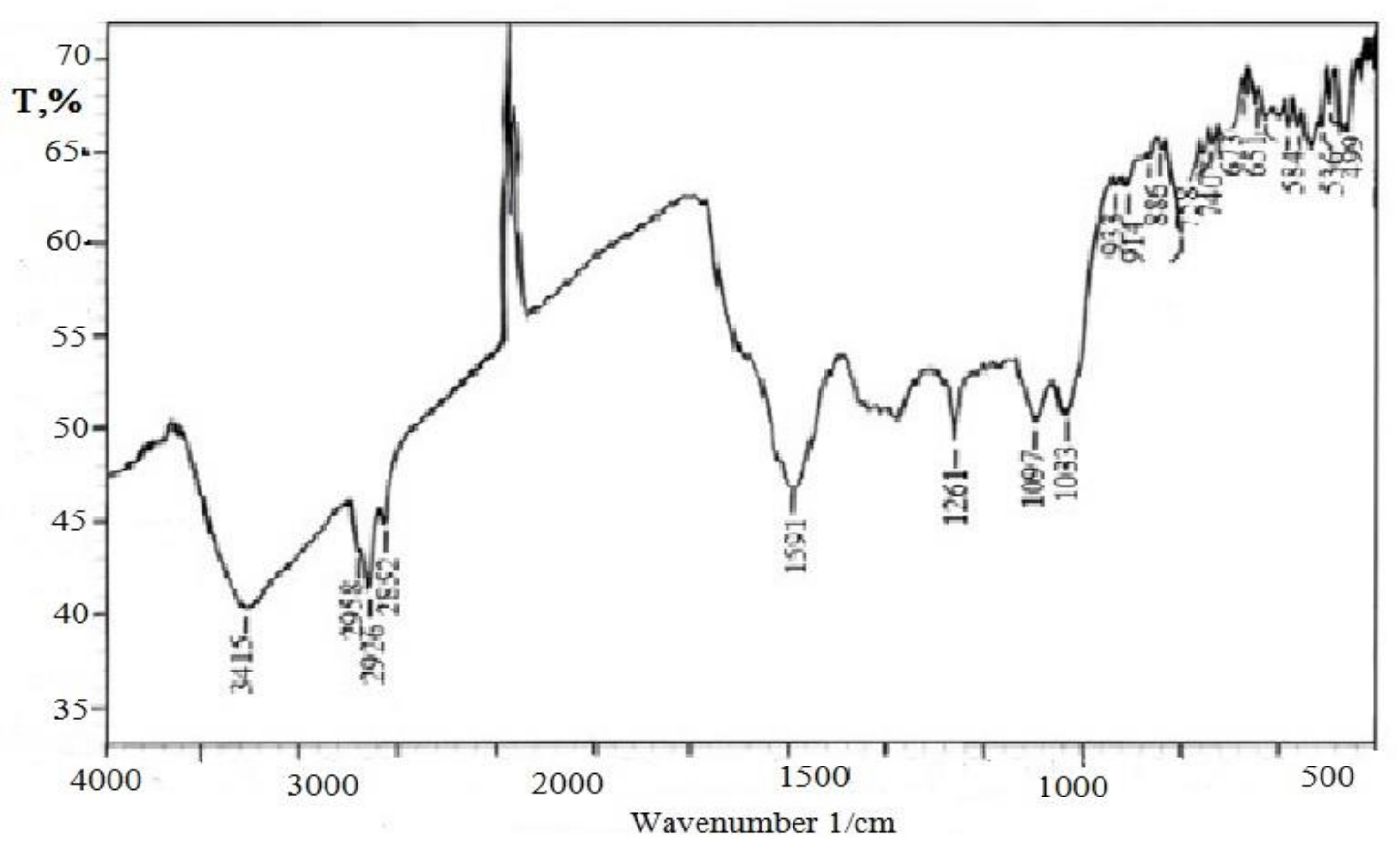

Figure 1. The IR spectra of coal from Shivee-Ovoo deposit.

In the IR spectra (Fig. 1) of Shivee-Ovoo coal there are several week absorption bands for $\mathrm{CH}$ aromatic group at $698,752,800 \mathrm{~cm}^{-1}$ and for aliphatic $-\mathrm{CH} ;-\mathrm{CH}_{2}$ and $-\mathrm{CH}_{3}$ groups with middle intensity at $1249 \mathrm{~cm}^{-1}$ and a sharp bands with higher intensity at 2854-2923 $\mathrm{cm}^{-1}$. And and also a strong absorption bands for $>\mathrm{C}=\mathrm{O}$ groups at $1600 \mathrm{~cm}^{-1}$, week bands for $-\mathrm{O}$ - groups at $1400 \mathrm{~cm}^{-1}$ and for C-O- groups at $1000,1050 \mathrm{~cm}^{-1}$. A unsharp and strong band for -OH and - $\mathrm{NH}$ groups at $3400 \mathrm{~cm}^{-1}$. Therefore the coal organic mass of Shivee-Ovoo coal consist mainly aliphatic, aromatic and aromatic-aliphatic structures with above mentioned groups inside.

The coal sample was burned completely and the ash was analyzed by roentgen-fluorescence analysis and determined the chemical composition for the characterization of inorganic matter of the coal from Shivee-Ovoo deposit (Table 2).

Table 2. Chemical composition of coal ash from the Shivee-Ovoo deposit (wt \%).

\begin{tabular}{|c|c|c|c|c|c|c|c|c|c|c|c|c|c|}
\hline $\mathrm{Na}_{2} \mathrm{O}$ & $\mathrm{MgO}$ & $\mathrm{Al}_{2} \mathrm{O}_{3}$ & $\mathrm{SiO}_{2}$ & $\mathrm{P}_{2} \mathrm{O}_{5}$ & $\mathrm{SO}_{3}$ & $\mathrm{~K}_{2} \mathrm{O}$ & $\mathrm{CaO}$ & $\mathrm{Mn}_{2} \mathrm{O}_{3}$ & $\mathrm{Fe}_{2} \mathrm{O}_{3}$ & $\mathrm{TiO}_{2}$ & $\mathrm{SrO}$ & $\mathrm{Cu}$ & $\mathrm{Zn}$ \\
\hline 1.33 & 5.21 & 10.53 & 27.72 & 0.57 & 18.21 & 1.4 & 28.87 & 0.62 & 5.72 & 0.81 & 0.19 & 0.01 & 0.04 \\
\hline
\end{tabular}

As seen in the Table 2, there are oxides of $\mathrm{CaO}$ and $\mathrm{SiO}_{2}$ have highest concentrations, oxides of $\mathrm{Al}_{2} \mathrm{O}_{3}, \mathrm{MgO}, \mathrm{SO}_{3}$ and $\mathrm{Fe}_{2} \mathrm{O}_{3}$ have medium concentrations and other oxides have low concentrations. To determine the character (acidic or basic) of of the coal was calculated the ratio between following sum oxides: $\mathrm{Fe}_{2} \mathrm{O}_{3}+\mathrm{CaO}+\mathrm{MgO}+\mathrm{Na}_{2} \mathrm{O}+\mathrm{K}_{2} \mathrm{O} / \mathrm{SiO}_{2}+\mathrm{Al}_{2} \mathrm{O}_{3}+\mathrm{Ti}_{2} \mathrm{O}>1$. The ration is less than 1 and it means the coal ash of Shivee-Ovoo deposit has a basic character.

The thermogravimetric analysis is a most useful method for the investigation on thermal decomposition (in argon atmosphere Hitachi, TG/DTA7300) and thermal stability of natural organic resources including coals.

The thermal decomposition of Shivee-Ovoo coal in argon gas was investigated by thermogravimetric analyzer in $20-1100{ }^{\circ} \mathrm{C}$ heating temperatures at different heating rates of 10,20,30,40 ${ }^{\circ} \mathrm{C} / \mathrm{min}$. and the TG, DTA and DTG curves are shown in Figure 2,3 and 4. 


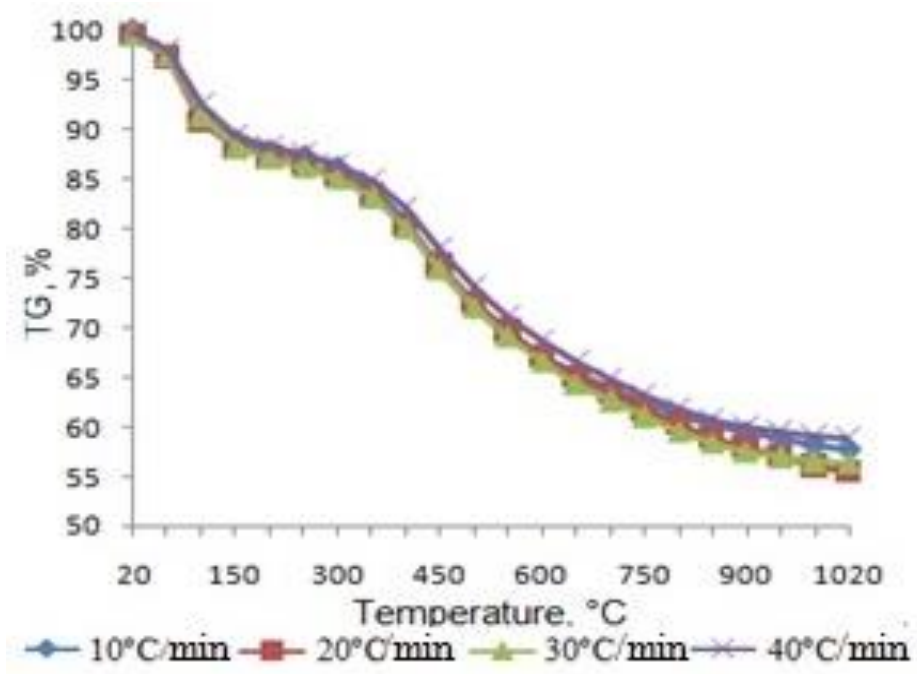

Figure 2. TG curves of the Shivee-Ovoo coal at different heating rates.

The TG curves (Fig. 2) of the Shivee-Ovoo coal at different heating rates show that all curves are similarly.

The heating of the Shivee-Ovoo coal sample at temperatures range $25-1000{ }^{\circ} \mathrm{C}$ and different heating rattes in nitrogen atmosphere show that the thermal decomposition of coal ended with a 55 $60 \%$ weight loss and $40-45 \%$ hard residue $1000{ }^{\circ} \mathrm{C}$ (Fig. 2). The TG curve in Fig. 3 consists of different temperature intervals (steps) such as $25-250 ; 250-550 ; 550-850 ; 850-1000{ }^{\circ} \mathrm{C}$. In the first step $\left(25-250{ }^{\circ} \mathrm{C}\right)$ the weight loss is due to the release of some absorbed gas and moisture from the coal sample. In the second step $\left(250-550{ }^{\circ} \mathrm{C}\right)$ intensive thermal decomposition of the organic matter of the coal samples start forming liquid (tar and pyrolysis water) and gas products. In the third step $\left(550-850{ }^{\circ} \mathrm{C}\right)$ the weight loss strongly decreases, which is an indication for ending the thermal decomposition and starting carbonization of the coal sample. In the fourth step $\left(850-1000{ }^{\circ} \mathrm{C}\right)$ the weight loss slowly increases, which is related with the release of gas, e.g. $\mathrm{CO}_{2}, \mathrm{H}_{2}, \mathrm{CO}$ from the mineral matter of coal sample.

From the TG curve in Fig. 2 have been determined the thermal stability indices $\left(\mathrm{T}_{5 \%}, \mathrm{~T}_{15 \%}, \mathrm{~T}\right.$ $25 \%$ ) of each heating rate of the Shivee-Ovoo coal and the results are given in Table 3.

Table 3. The the thermal stability indices of the Shivee-Ovoo coal.

\begin{tabular}{|l|l|l|l|l|}
\hline \multirow{2}{*}{ No } & Heating rates, ${ }^{0} \mathrm{C} / \mathrm{min}$. & \multicolumn{3}{|c|}{ Thermal stability indices, ${ }^{0} \mathrm{C}$} \\
\cline { 3 - 5 } & & $T_{5 \%}$ & $T_{15 \%}$ & $T_{25 \%}$ \\
\hline 1. & $10{ }^{0} \mathrm{C} / \mathrm{min}$. & 68.43 & 330.89 & 330.89 \\
\hline 2. & $20{ }^{0} \mathrm{C} / \mathrm{min}$. & 67.46 & 308.81 & 465.18 \\
\hline 3. & $30{ }^{0} \mathrm{C} / \mathrm{min}$. & 71.75 & 300.97 & 461.55 \\
\hline 4. & $40{ }^{0} \mathrm{C} / \mathrm{min}$. & 79.76 & 344.06 & 490.64 \\
\hline & Averaged $25{ }^{0} \mathrm{C} / \mathrm{min}$. & 71.85 & 321.18 & 437.07 \\
\hline
\end{tabular}

On the basis of the determined thermal indices in Table 3 have been calculated an averaged heating rate $-25{ }^{\circ} \mathrm{C} / \mathrm{min}$. and related averaged thermal stability indices as $\mathrm{T}_{5 \%}=71,85^{\circ} \mathrm{C} ; \mathrm{T}_{15 \%}=321,18^{\circ} \mathrm{C}$; $\mathrm{T} 25 \%=437.07^{\circ} \mathrm{C}$ for Shivee-Ovoo coal. These indices indicate that the organic mass of ShiveeOvoo coal has a lower thermal stability or easy decomposes under heating. 


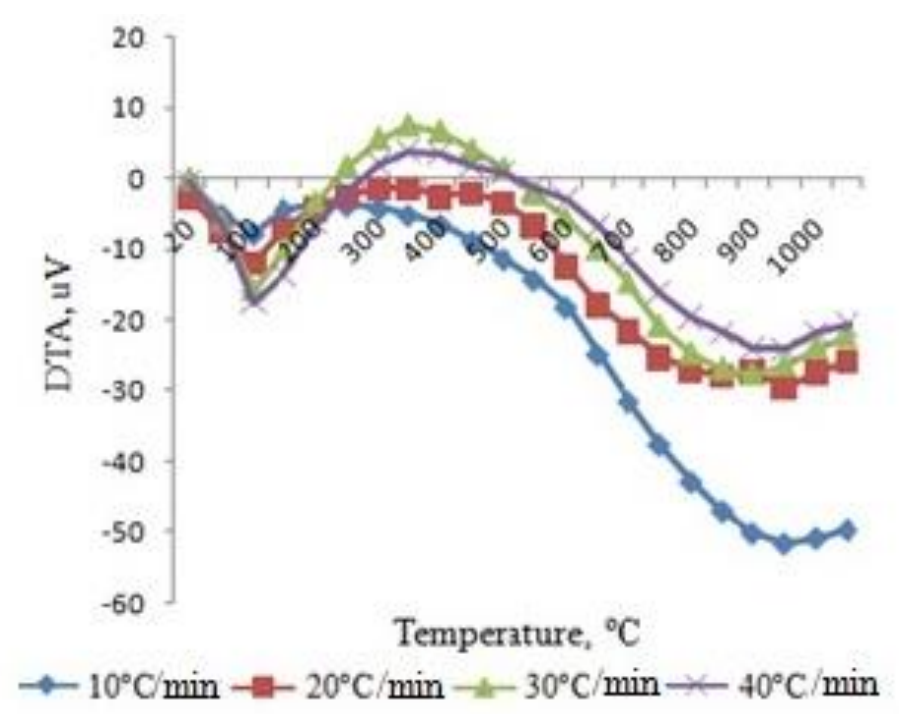

Figure 3. DTA curves of the Shivee-Ovoo coal at different heating rates.

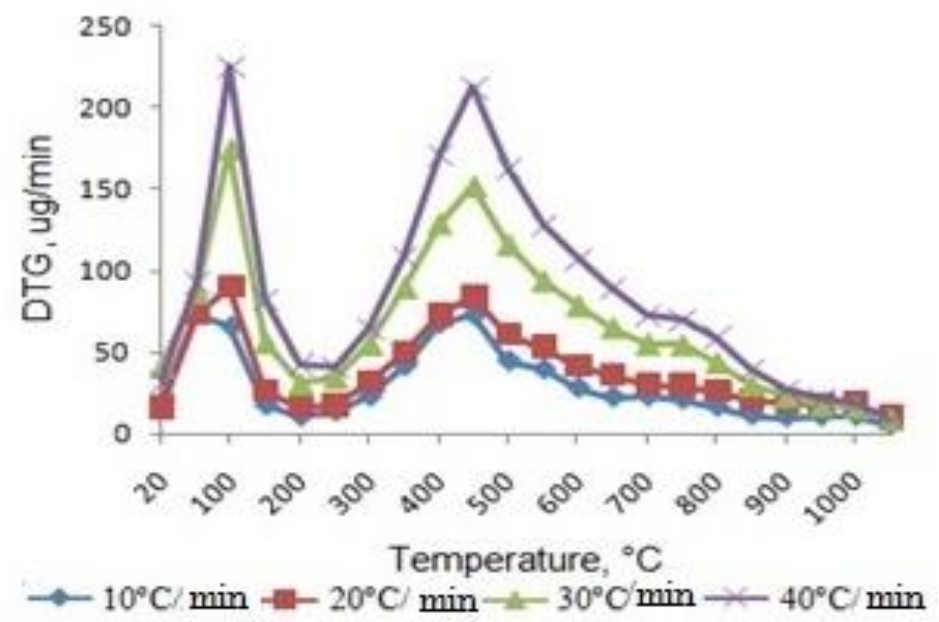

Figure 4. DTG curves of the Shivee-Ovoo coal at different heating rates.

First minimum peak of DTA at $160{ }^{\circ} \mathrm{C}$ shows a endothermic reaction process related with releasing adsorbed gas and moisture from the coal organic mass of the sample. And a bid exothermic reaction peak at $400{ }^{\circ} \mathrm{C}$ related with intensive thermal destruction of the organic mass of the coal sample. The DTG curves in Figure 3 consist of 2 zones and indicate clearly increasing the decomposition rate of coal organic mass vs increasing of heating rate. If you look at DTG curve releasing of moisture and adsorbed gas at about $100{ }^{\circ} \mathrm{C}$ and and also thermal destruction reactions of coal organic mass at about $450{ }^{\circ} \mathrm{C}$ are with maximum rate.

The pyrolysis is a one of the often used thermal processing of brown coals to produce a solid (hard residue or char or semicoke), condensed liquid (tar) and uncondensed gas product. For this reason the Shivee-Ovoo coal was pyrolized in a standard quartz retort at different heating temperatures $\left(200^{\circ} \mathrm{C}-700^{\circ} \mathrm{C}\right.$ ) for $80 \mathrm{~min}$. and determined the yields of char, tar, pyrolysis water and gas (Fig. 5). 


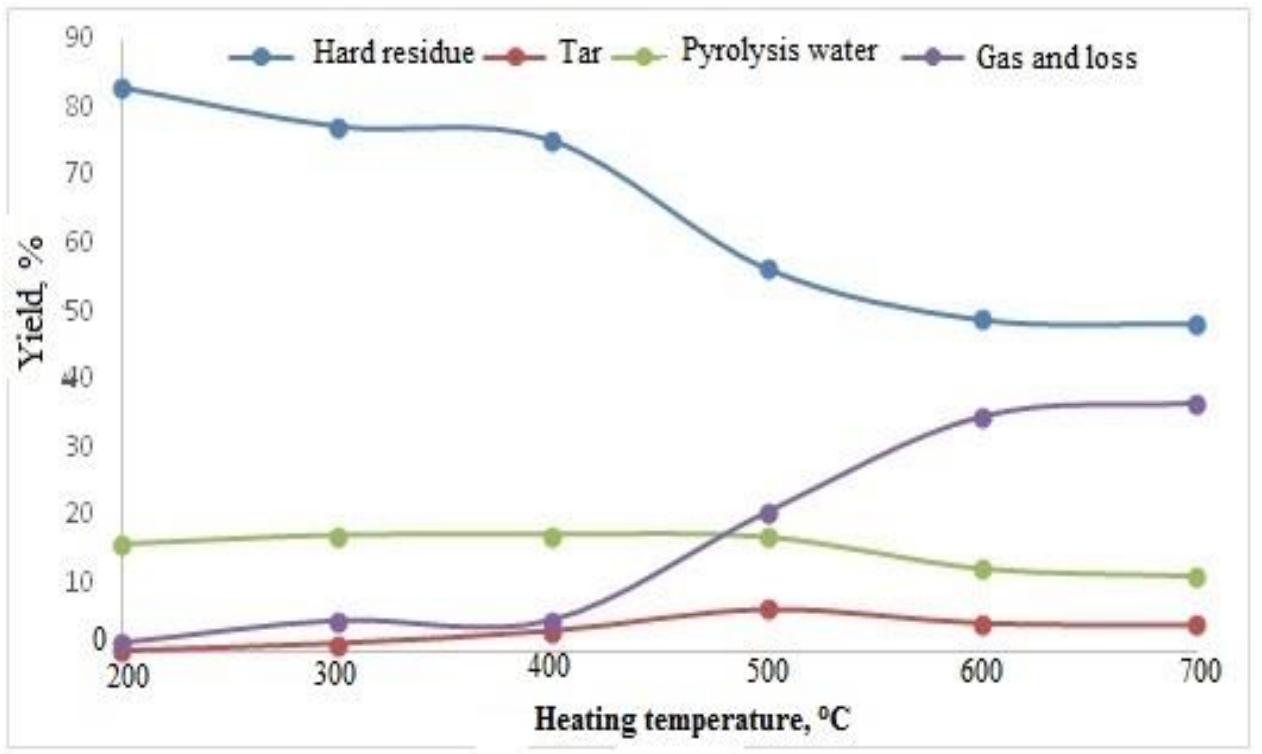

Figure 5. The yields of pyrolysis products vs different heating temperatures.

The results of the pyrolysis of Shivee-Ovoo coal in Figure 5 show that the optimal heating temperature is $500^{\circ} \mathrm{C}$, in which the yield of tar (most important product of the pyrolysis) is higher. The yield of all thermal decomposition products such as liquid and gas products (44\%) shows that there is an intensive thermal decomposition of the coal organic mass with higher degree of conversion. As it is known that the organic mass of low rank brown coal (lignite) characterizes with lower thermal stability than high rank (bituminous) coal and therefore brown coals are more suitable for gasification and liquefaction.

The solid product (hard residue or semicoke) after the pyrolysis Shivee-Ovoo coal is one of the main product and can be used as smokeless fuel and activated carbon after briquetting and activation. For this reason have determined the main technical characteristics of the hard residue and compared with the same characteristics of the initial coal (Table 4).

Table 4. Main technical characteristics of the pyrolysis hard residue and initial coal of Shivee-Ovoo deposit.

\begin{tabular}{|l|l|l|l|l|l|}
\hline No & \multirow{2}{*}{ Shivee-Ovoo coal } & \multicolumn{4}{|c|}{ Main technical characteristics, \% } \\
\cline { 3 - 6 } & $\begin{array}{l}\text { Moisture, } \\
\mathrm{W}^{\mathrm{a}}\end{array}$ & $\begin{array}{l}\text { Ash, } \\
\mathrm{A}^{\mathrm{d}}\end{array}$ & $\begin{array}{l}\text { Volatile } \\
\text { matters, } \\
\mathrm{V}^{\text {daf }}\end{array}$ & $\begin{array}{l}\text { Caloric value, } \\
\mathrm{Q}^{\text {daf }}, \text { ккаl/кg }\end{array}$ \\
\hline 1. & Initial coal & 13,41 & 21,17 & 42,57 & 6501.20 \\
\hline 2. & Pyrolysis hard residue & 0,10 & 27,42 & 16,20 & 7337.96 \\
\hline
\end{tabular}

The proximate analysis results of hard residue after pyrolysis of Shivee-Ovoo coal in Table 3 show that the volatile matter content decreased 3 times and increased caloric value in comparison with the initial coal characteristics, indicating that it can be used as smokeless fuel [8].

One of the most important applications of the hard residue after thermal processing is to produce activated carbon. For this reason the hard residue produced after pyrolysis was activated by preheated water steam at $800{ }^{\circ} \mathrm{C}$ for $120 \mathrm{~min}$.

The images of scanning electron microscopes (SEM) of prepared activated carbon from pyrolyzed hard residue (Fig. 6 B) in comparison with initial coal sample (Figure 6 A) are different as presented in Fig. 6. 

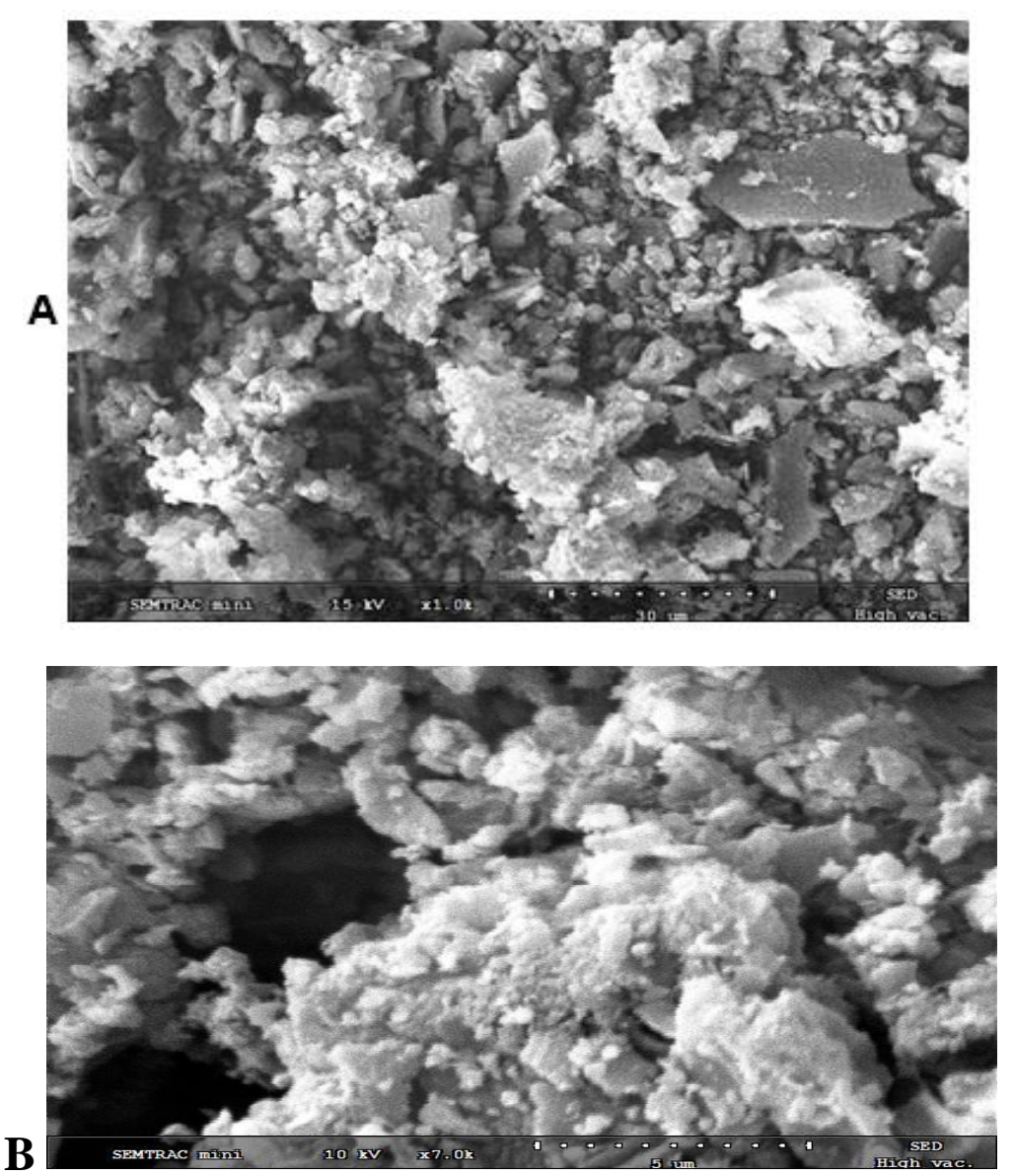

Figure 6. The SEM photograph of initial coal sample of Shivee-Ovoo (A) and its activated carbon sample $(\mathbf{B})$.

The SEM image of initial coal sample (Fig. 6A) has compact solid pieces. The SEM images of carbonized and activated coal sample (Fig. 6 B) show porosity structure with meso and macro pores in comparison with that of initial coal sample.

As it was mentioned above the pyrolysis tar of Shivee-Ovoo coal is most important product with unknown properties and composition. Therefore we focused on more detailed investigation of this tar.

First of all the tar was completely removed from the pyrolysis water by, centrifuging and drying with thermally treated calcium chloride and filtering. So purified tar tested by IR analysis and the FT IR spectra is shown in Figure 7.

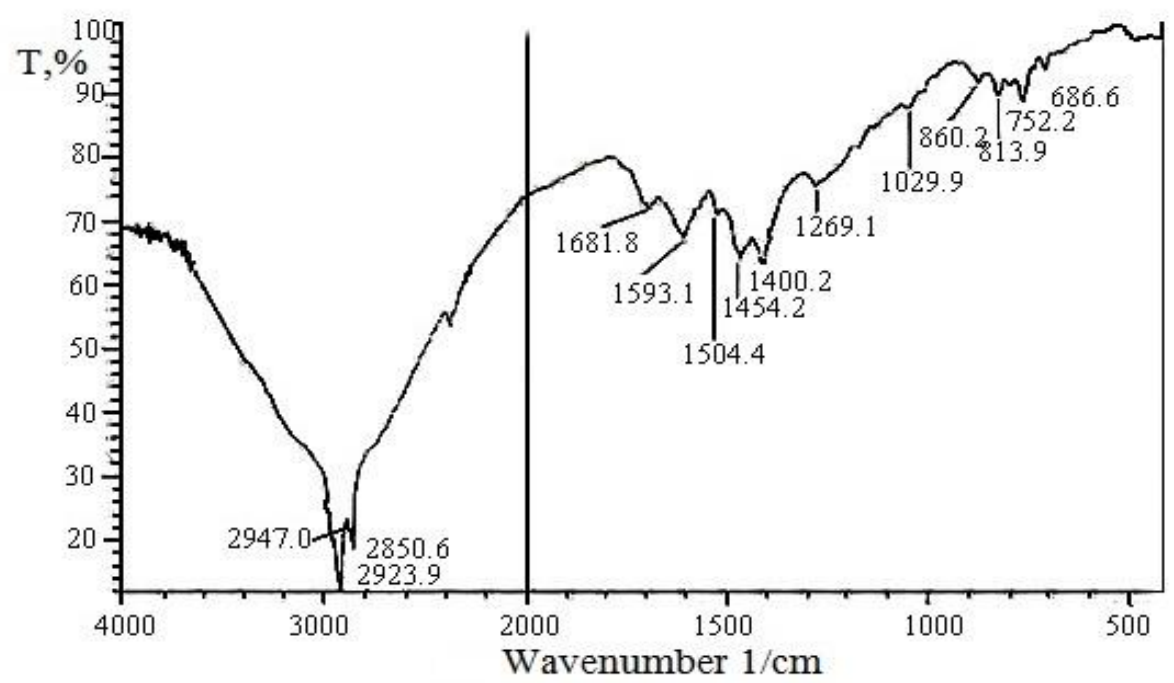

Figure 7. The FTIR spectra of liquid tar product after pyrolysis. 
In the FTIR spectra of tar product after pyrolysis, low intensity absorption bands were observed for $\mathrm{H}$ of aromatic $-\mathrm{CH}$ group at $686,752,813 \mathrm{~cm}^{-1}$ and for $\mathrm{H}$ of aliphatic $-\mathrm{CH}$; $-\mathrm{CH}_{2}$ and $\mathrm{CH}_{3}$ groups at $1269 \mathrm{~cm}^{-1}$ and their sharp bands with highest intensity at $2850-2947 \mathrm{~cm}^{-1}$. Absorption bands with middle intensity for $\mathrm{O}$ containing groups such as for $>\mathrm{C}=\mathrm{O}$ groups at 1593 $\mathrm{cm}^{-1}$, for -O- groups at $1454 \mathrm{~cm}^{-1}$. Therefore the tar product of Shivee-Ovoo coal after pyrolysis consists of mainly aliphatic, aromatic and aromatic-aliphatic compounds with above mentioned functional groups in their molecules.

The chemical composition of the tar determined by chemical analysis in group organic compounds and the results are given in Table 5.

Table 5. The chemical composition of the tar in group organic compounds.

\begin{tabular}{|l|l|l|l|l|l|l|}
\hline Sample & \multicolumn{6}{|l|}{ The chemical composition of the tar, mac. \% } \\
\cline { 2 - 7 } & $\begin{array}{l}\text { free } \\
\text { carbons }\end{array}$ & $\begin{array}{l}\text { organic } \\
\text { bases }\end{array}$ & $\begin{array}{l}\text { organic } \\
\text { acids }\end{array}$ & phenols & asphalteins & $\begin{array}{l}\text { neutral } \\
\text { oils }\end{array}$ \\
\hline $\begin{array}{l}\text { pyrolysis tar of Shivee- } \\
\text { Ovoo coal }\end{array}$ & 3.93 & 0.25 & 0.06 & 0.8 & 13.06 & 81.9 \\
\hline
\end{tabular}

The date in Table 5 show that the neutral oils are the main component with highest and asphalteins, free carbons are with middle content. The contents of organic bases, organic acids and phenols are lowest.

Also the pyrolysis tar of Shivee-Ovoo coal was tested by an air distillation and obtained several fractions with different boiling temperature ranges and the the yield and some other determined properties are given in Table 6.

Table 6. The yields of pyrolysis tar of Shivee-Ovoo coal.

\begin{tabular}{|l|l|l|l|l|}
\hline $\begin{array}{l}\text { Boiling } \\
\text { temperature } \\
\text { range, }{ }^{0} \mathrm{C}\end{array}$ & $\begin{array}{l}\text { Yield } \\
\text { fraction, \% }\end{array}$ & $\begin{array}{l}\text { Refractive } \\
\text { index }\end{array}$ & Color & Description \\
\hline $\begin{array}{l}\text { Startin loiling - } \\
180^{\circ} \mathrm{C}\end{array}$ & 15,93 & 1,342 & yellow & light fractions \\
\hline $180-330^{\circ} \mathrm{C}$ & 15,44 & 1,529 & brown & $\begin{array}{l}\text { meddle } \\
\text { fractions }\end{array}$ \\
\hline $\begin{array}{l}\text { More than } \\
330^{\circ} \mathrm{C}\end{array}$ & 44,53 & - & $\begin{array}{l}\text { Black- } \\
\text { brown }\end{array}$ & heavy fractions \\
\hline loss & 24,10 & - & - & - \\
\hline
\end{tabular}

The date in Table 6 show that the main product of distillation of the pyrolysis tar of ShiveeOvoo coal is the heavy fractions, followed light and middle fractions with same yields. After removing of the toxic organic compounds such as organic bases, organic acids and phenols these fractions can be used as gasoline (light fractions), diesel (middle fractions) and oil products (heavy fractions).

As mentioned above organic bases and organic acids were removed from the pyrolysis tar of Shivee-Ovoo coal and so purified tar is called as a "neutral oil"'.

The solubility in hexane, toluene and methylenchloride-methanol and chemical composition of the neutral oil investigated by silicagel chromatograpy and GC/MS analysis and the results of GC/MS chromatograms are presented in Figs. 8, 9 and 10. 


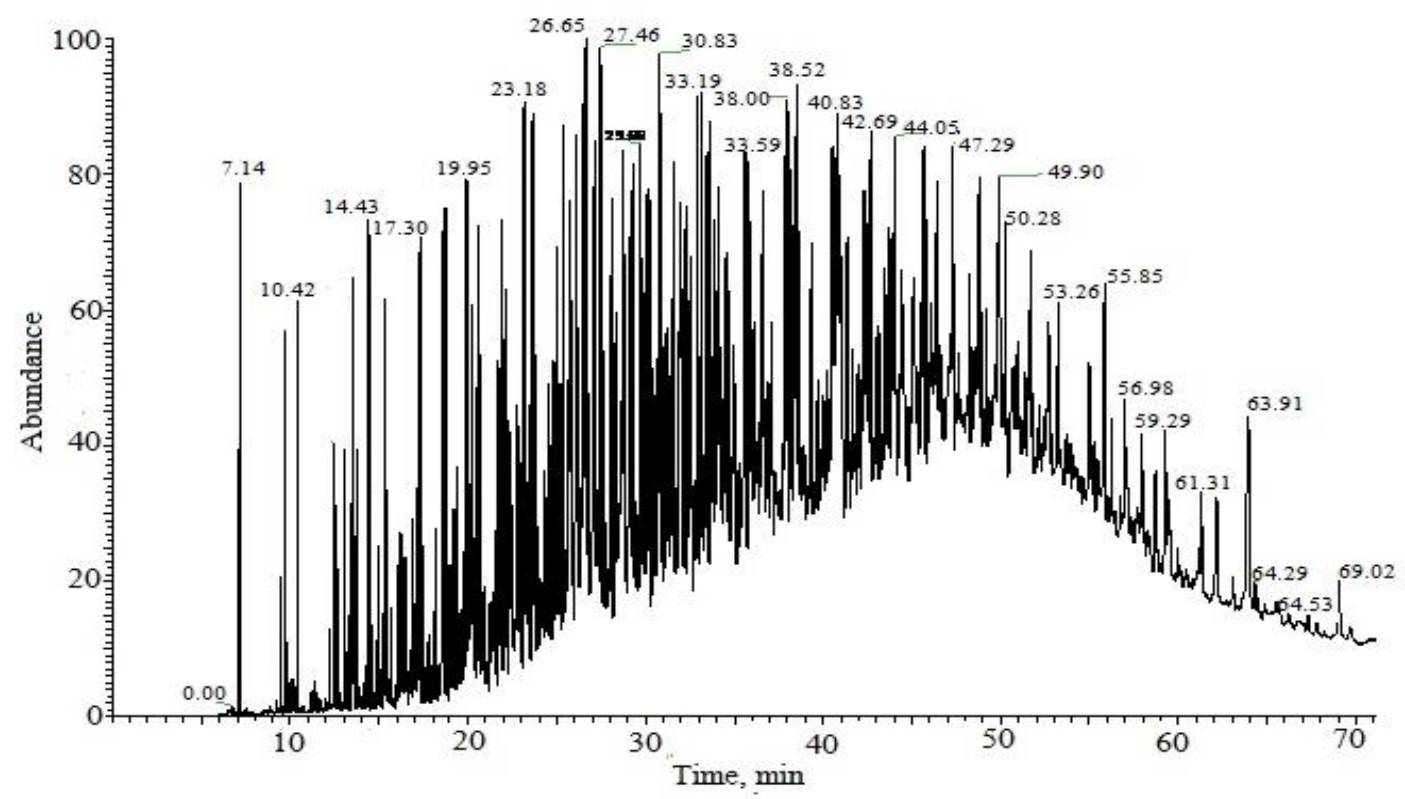

Figure 8. GC/MS chromatogram of soluble in hexane fraction of the neutral oil from the pyrolysis tar of Shivee Ovoo coal.

On the bases of Fig. 8 and Appendix-1 summarized all aliphatic compounds and the results are given in Table 7 .

Table 7. The identified aliphatic compounds of soluble in hexane fraction of the neutral oil from the pyrolysis tar of the Shivee Ovoo coal.

\begin{tabular}{|l|l|}
\hline Identified aliphatic compounds & Content, \% \\
\hline Alkanes $\mathrm{C}_{6}-\mathrm{C}_{35}$ & 13.92 \\
\hline CycloalkaHes $\mathrm{C}_{7}-\mathrm{C}_{35}$ & 10.59 \\
\hline Alkenes $\mathrm{C}_{7}-\mathrm{C}_{35}$ & 18.28 \\
\hline Total & $\mathbf{4 2 . 7 9}$ \\
\hline
\end{tabular}

The date in Table 7 show that the most identified aliphatic compounds are $\mathrm{C}_{6}-\mathrm{C}_{35}$ paraffins, $\mathrm{C}_{7}-\mathrm{C}_{35}$ alkens, and $\mathrm{C}_{7}-\mathrm{C}_{35}$ cycloalkenes. All 22 compounds identified from all registered 68 peaks in the GC/MS chromatogram of soluble in hexane fraction of the neutral oil from the pyrolysis tar of Shivee Ovoo coal (Appendix-1).

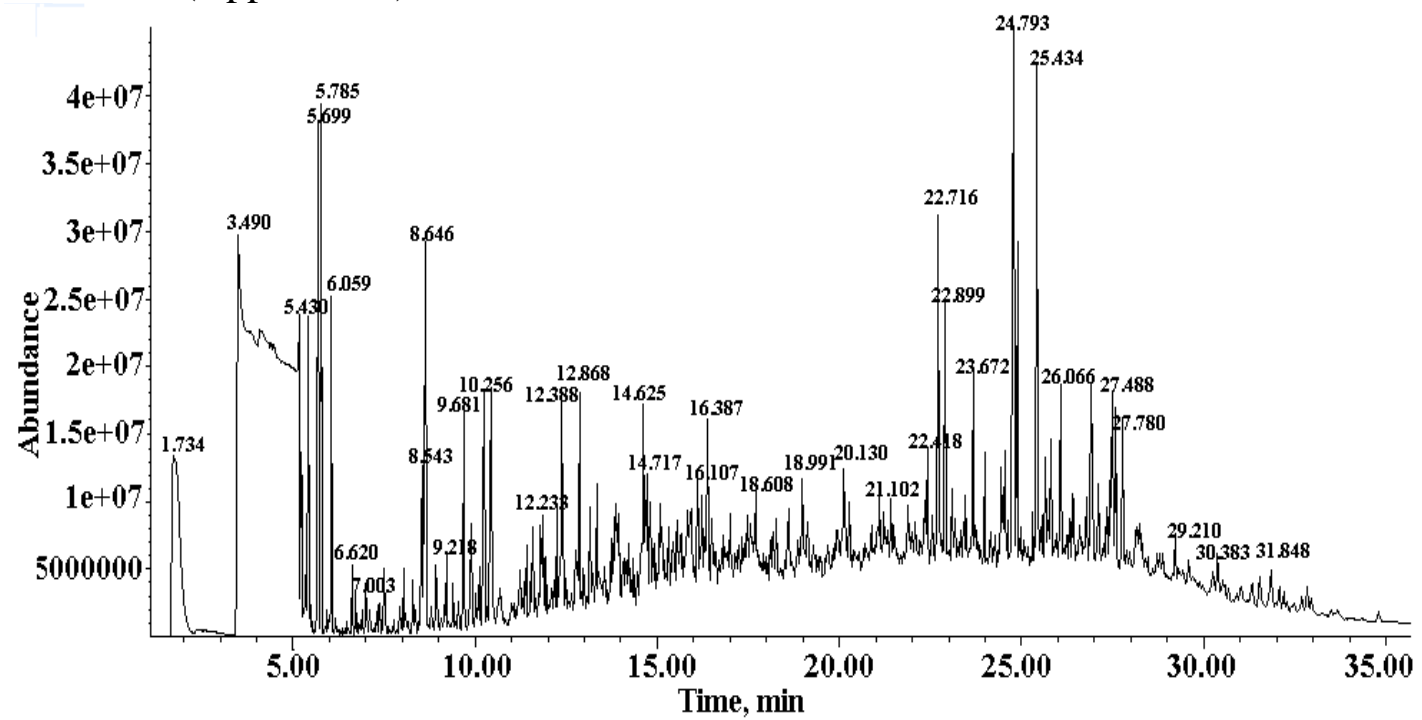

Figure 9. GC/MS chromatogram of soluble in toluene fraction of the neutral oil from the pyrolysis tar of Shivee Ovoo coal. 
On the bases of Fig. 9 and Appendix-1 summarized all aromatic compounds and the results are given in Table 8.

Table 8. The identified aromatic compounds of soluble in toluene fraction of the neutral oil from the pyrolysis tar of the Shivee Ovoo coal.

\begin{tabular}{|c|c|c|}
\hline \multicolumn{2}{|c|}{ Identified aromatic compounds } & content, \% \\
\hline \multirow{2}{*}{1 cyclo aromatics } & $\mathrm{C}_{7}$ & 3.26 \\
\cline { 2 - 3 } & $\mathrm{C}_{8}$ & 8.88 \\
\cline { 2 - 3 } & $\mathrm{C}_{9}$ & 14.55 \\
\cline { 2 - 3 } & $\mathrm{C}_{10}$ & 4.19 \\
\hline \multirow{2}{*}{2 cyclo aromatics } & Naphthalene, their derivatives & 8.02 \\
\hline \multirow{2}{*}{3 cyclo aromatics } & $\begin{array}{c}\text { Anthracene and phenanthrene, their } \\
\text { derivatives }\end{array}$ & 8.87 \\
\hline 4 cyclo aromatics & Pyrene, their derivatives & 3.75 \\
\hline \multicolumn{2}{|c|}{ heteroatom aromatic compounds } & 28.21 \\
\hline \multicolumn{2}{|c|}{ total } & 79.73 \\
\hline
\end{tabular}

The date in Table 8 show that the most identified aromatic compounds are monocyclic and polycyclic aromatic compounds such as $\mathrm{C}_{7}-\mathrm{C}_{10}$ derivatives of benzene, 2 cyclo aromatics such as derivatives of naphthalene, 3 cyclo aromatics such as derivatives of anthracene and phenanthrene, 4 cyclo aromatics such as derivatives of pyrene and some heteroatomic aromatic compounds in the soluble in toluene fraction of the neutral oil from the pyrolysis tar of Shivee Ovoo coal.

All 45 compounds identified from all registered 100 peaks in the GC/MS chromatogram of soluble in toluene fraction of the neutral oil from the pyrolysis tar of Shivee Ovoo coal (Appendix1).

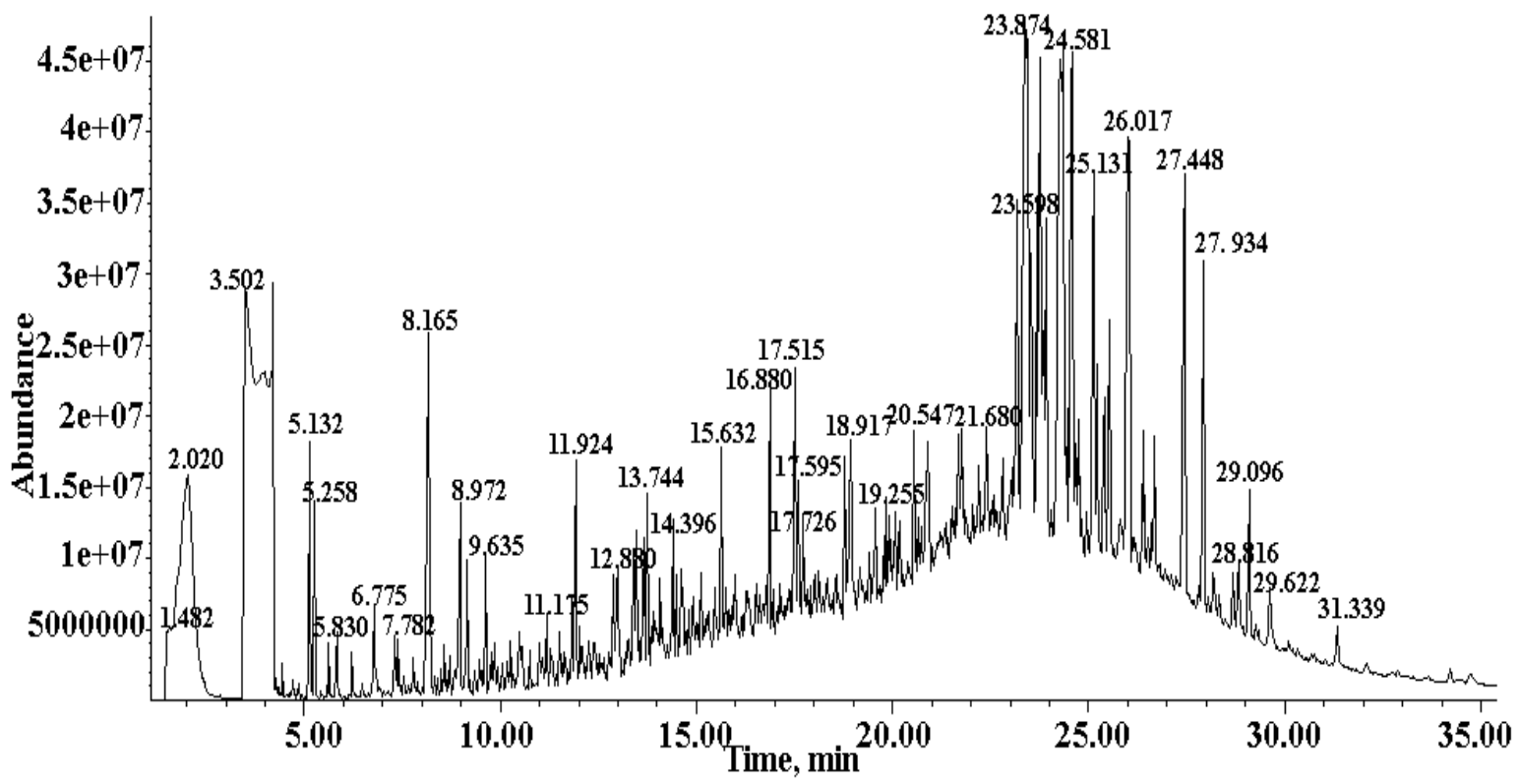

Figure 10. GC/MS chromatogram of soluble in methylenchloride-methanol fraction of the neutral oil from the pyrolysis tar of Shivee Ovoo coal.

On the bases of Fig. 10 and Appendix-1 summarized all oxygen containing organic compounds and the results are given in Table 9. 
Table 9. The identified oxygen containing organic compounds of soluble in methylenchloridemethanol fraction of the neutral oil from the pyrolysis tar of the Shivee Ovoo coal.

\begin{tabular}{|l|l|}
\hline Identified compounds & content, \% \\
\hline Alcohols & 22.59 \\
\hline Phenols & 7.94 \\
\hline Esters & 1.59 \\
\hline heteroatom compounds (nitrile) & 2.44 \\
\hline total & $\mathbf{3 4 . 5 6}$ \\
\hline
\end{tabular}

The date in Table 9 show that the most identified oxygen containing organic compounds are aliphatic alcohols, phenols, esters and heteroatomic compounds such asnitriles in the soluble in methylenchloride-methanol fraction of the neutral oil from the pyrolysis tar of Shivee Ovoo coal.

All 21 compounds identified from all registered 100 peaks in the GC/MS chromatogram of soluble in in methylenchloride-methanol fraction of the neutral oil from the pyrolysis tar of Shivee Ovoo coal (Appendix-1).

\section{Conclusions}

1. On the basis of proximate and ultimate analysis have been confirmed that the Shivee-Ovoo coal is a low-rank lignite coal of B2 mark and it is suitable for thermal processing including pyrolysis.

2. The thermal degradation process of Shivee-Ovoo coal was investigated by thermogravimetric analyzer and first time determined the thermal stability of the coal sample by determination of thermal indices such as $\mathrm{T}_{5 \%}-71.85^{\circ} \mathrm{C} ; \mathrm{T}_{15 \%}-321.18^{\circ} \mathrm{C} ; \mathrm{T}_{25 \%}-490.64^{\circ} \mathrm{C}$ from the $\mathrm{TG}$ curve, which are the characteristics of lower thermal stability.

3. The results of pyrolysis experiment of Shivee-Ovoo coal show that $56.00 \%$ of coal organic mass remained as a hard residue after pyrolysis. The yield of all liquid and gas products is $44.00 \%$ at the optimal heating temperature $500^{\circ} \mathrm{C}$, which is showing that there was an intensive thermal decomposition of the coal organic mass with higher degree of conversion.

4. The determined chemical composition of pyrolysis tar of Shivee-Ovoo coal in group organic compounds by chemical analysis show that the tar consists mostly neutral oils with highest content-81,9\%, asphalteines $-13.6 \%$, free carbons $-3.93 \%$ and organic bases, organic acids, phenolic compounds are less than $1.0 \%$.

5. The pyrolysis tar of Shivee-Ovoo coal also was distilled at room temperature and obtained several fractions with different boiling temperature ranges including yellow colored light fraction $-15.93 \%\left(18-180^{\circ} \mathrm{C}\right)$, brown colored middle fraction $-15.44 \%\left(180-330^{\circ} \mathrm{C}\right)$ and black colored heavy fraction $-44.53 \%(330>0$ C).

6. The proximate analysis results of hard residue after pyrolysis of Shivee-Ovoo coal show that the volatile matter content decreased 3 times and increased caloric value in comparison with the initial coal characteristics, indicating that there was an intensive thermal decomposition of the coal organic mass and it can be used as smokeless fuel.

7. The images of scanning electron microscopes (SEM) of prepared activated carbon from pyrolyzed hard residue in comparison with initial coal sample are different. The SEM image of initial coal sample has compact solid pieces. The SEM image of carbonized and activated coal sample shows a porosity structure with meso and macro pores in comparison with that of initial coal sample.

8. The solubility and chemical composition of neutral oil isolated from the pyrolysis tar of ShiveeOvoo coal investigated by GC/MS analysis and registered totally 68 peaks (signals) for the soluble in hexane, 100 peaks for the soluble in toluene and 100 peaks for the soluble in a mixed solvent of methylenchloride and methanol fractions. Have been determined and identified 22 organic compounds soluble in hexane, 45 organic compounds soluble in toluene and 21 organic compounds soluble in a mixed solvent of methylenchloride and methanol fractions from each related totally registered peaks. 


\section{Conflict of Interest}

The authors declare that there is no conflict of interest.

\section{Appendix-1. The name of identified organic compounds by GC/MS analysis}

\begin{tabular}{|c|c|c|c|c|c|c|c|c|}
\hline \multicolumn{3}{|c|}{ Soluble in Hexane fraction } & \multicolumn{3}{|c|}{ Soluble in toluene fraction } & \multicolumn{3}{|c|}{$\begin{array}{l}\text { Soluble in methylenchloride and } \\
\text { methanol fraction }\end{array}$} \\
\hline $\begin{array}{l}\text { R.T } \\
\text { min }\end{array}$ & $\begin{array}{l}\% \text { of } \\
\text { total }\end{array}$ & $\begin{array}{l}\text { The name of } \\
\text { determined } \\
\text { organic } \\
\text { substances }\end{array}$ & $\begin{array}{l}\text { R.T } \\
\min \end{array}$ & $\begin{array}{l}\% \text { of } \\
\text { total }\end{array}$ & $\begin{array}{c}\text { The name of } \\
\text { determined organic } \\
\text { substances }\end{array}$ & R.T min & $\begin{array}{l}\% \text { of } \\
\text { total }\end{array}$ & $\begin{array}{c}\text { The name of } \\
\text { determined organic } \\
\text { substances }\end{array}$ \\
\hline 1.241 & 0.000 & & 1.734 & 8.230 & & 1.482 & 0.181 & \\
\hline 1.270 & 0.000 & & 3.490 & $\begin{array}{l}15.90 \\
6\end{array}$ & & 2.020 & 9.655 & \\
\hline 1.310 & 0.000 & & 5.207 & 0.263 & & 3.502 & 13.42 & $\begin{array}{l}\text { methyl benzene } \\
\mathrm{C}_{7} \mathrm{H}_{8}\end{array}$ \\
\hline 1.321 & 0.000 & & 5.230 & 0.255 & & 5.132 & 0.911 & ethyl benzene $\mathrm{C}_{8} \mathrm{H}_{10}$ \\
\hline 1.510 & 0.007 & & 5.258 & 0.312 & & 5.258 & 0.654 & \\
\hline 1.665 & 1.216 & $\begin{array}{l}\text { methylene } \\
\text { chloride } \mathrm{CH}_{2} \\
\mathrm{CL}_{2}\end{array}$ & 5.401 & 0.585 & & 5.630 & 0.158 & \\
\hline 1.854 & 0.527 & & 5.430 & 0.943 & & 5.830 & 0.285 & \\
\hline 2.243 & 1.399 & $\begin{array}{l}\text { methylene } \\
\text { pentane } \mathrm{C}_{6} \mathrm{H}_{14}\end{array}$ & 5.699 & 3.834 & $\begin{array}{l}\text { ethyl benzene }\left(\mathrm{C}_{8} \mathrm{H}_{10}\right) \\
106\end{array}$ & 6.219 & 0.187 & \\
\hline 2.443 & 2.077 & $\begin{array}{l}\text { Cyclo hexane } \\
\mathrm{C}_{6} \mathrm{H}_{12}\end{array}$ & 5.785 & 3.451 & $\begin{array}{l}\text { dimethyl benzene } \\
\left(\mathrm{C}_{8} \mathrm{H}_{10}\right)\end{array}$ & 6.775 & 0.402 & \\
\hline 3.433 & 0.707 & $\begin{array}{l}\text { heptatriene } \\
\mathrm{C}_{7} \mathrm{H}_{10}\end{array}$ & 6.059 & 1.321 & $\begin{array}{l}\text { dimethyl benzene } \\
\left(\mathrm{C}_{8} \mathrm{H}_{10}\right)\end{array}$ & 7.318 & 0.389 & \\
\hline 3.547 & 8.387 & $\begin{array}{l}\text { heptatriene } \\
\mathrm{C}_{7} \mathrm{H}_{10}\end{array}$ & 6.620 & 0.298 & & 7.392 & 0.239 & \\
\hline 3.914 & 0.182 & & 7.003 & 0.360 & & 7.787 & 0.168 & \\
\hline 4.034 & 0.108 & & 7.301 & 0.428 & & 8.165 & 3.168 & $\begin{array}{l}\text { methanol benzene } \\
\mathrm{C}_{7} \mathrm{H}_{8} \mathrm{O}\end{array}$ \\
\hline 4.125 & 0.041 & & 8.039 & 0.297 & & 8.577 & 0.185 & \\
\hline 4.200 & 0.022 & & 8.297 & 0.292 & & 8.703 & 0.175 & \\
\hline 4.257 & 0.033 & & 8.543 & 1.576 & $\begin{array}{l}\text { trimethyl } \\
\text { cyclopentenone } \\
\left(\mathrm{C}_{8} \mathrm{H}_{12} \mathrm{O}\right)\end{array}$ & 8.823 & 0.169 & \\
\hline 4.406 & 0.006 & & 8.646 & 3.565 & $\begin{array}{l}\text { phenyl ethanone } \\
\left(\mathrm{C}_{8} \mathrm{H}_{8} \mathrm{O}\right)\end{array}$ & 8.972 & 0.891 & $\begin{array}{l}\text { trimethyl } \\
\text { cyclopentenone } \\
\mathrm{C}_{8} \mathrm{H}_{12} \mathrm{O}\end{array}$ \\
\hline 4.446 & 0.024 & & 8.932 & 0.484 & & 9.166 & 0.497 & \\
\hline 4.594 & 0.122 & & 9.218 & 0.309 & & 9.470 & 0.154 & \\
\hline 4.646 & 0.077 & & 9.681 & 1.010 & $\begin{array}{l}\text { methyl phenyl } \\
\text { ethanone }\left(\mathrm{C}_{9} \mathrm{H}_{10} \mathrm{O}\right)\end{array}$ & 9.635 & 0.588 & \\
\hline 4.795 & 0.231 & & 9.899 & 0.958 & $\begin{array}{l}\text { trimethyl pyrazole } \\
\left(\mathrm{C}_{6} \mathrm{H}_{10} \mathrm{~N}_{2}\right)\end{array}$ & 9.779 & 0.154 & \\
\hline 5.052 & 2.449 & $\begin{array}{l}\text { ethyl benzene } \\
\mathrm{C}_{8} \mathrm{H}_{10}\end{array}$ & 10.025 & 0.236 & & 9.853 & 0.167 & \\
\hline 5.235 & 3.796 & $\begin{array}{l}\text { dimethyl } \\
\text { benzene } \mathrm{C}_{8} \mathrm{H}_{10}\end{array}$ & 10.111 & 0.336 & & 9.927 & 0.124 & \\
\hline 5.327 & 0.621 & & 10.236 & 2.017 & $\begin{array}{l}\text { methyl phenyl } \\
\text { ethanone } \mathrm{C}_{6} \mathrm{H}_{10} \mathrm{O}\end{array}$ & 10.179 & 0.120 & \\
\hline 5.630 & 5.483 & $\begin{array}{l}\text { ethenyl benxene } \\
\mathrm{C}_{8} \mathrm{H}_{8}\end{array}$ & 10.437 & 1.752 & $\begin{array}{l}\text { methyl phenyl } \\
\text { ethanone } \mathrm{C}_{6} \mathrm{H}_{10} \mathrm{O}\end{array}$ & 10.265 & 0.181 & \\
\hline 5.699 & 1.433 & nonane $\mathrm{C}_{9} \mathrm{H}_{20}$ & 11.243 & 0.486 & & 10.488 & 0.432 & \\
\hline 5.790 & 0.387 & & 11.415 & 0.358 & & 10.746 & 0.140 & \\
\hline 5.888 & 0.098 & & 11.581 & 0.484 & & 10.992 & 0.201 & \\
\hline
\end{tabular}




\begin{tabular}{|c|c|c|c|c|c|c|c|c|}
\hline 5.922 & 0.116 & & 11.798 & 0.479 & & 11.175 & 0.298 & \\
\hline 5.985 & 0.307 & & 11.867 & 0.507 & & 11.283 & 0.164 & \\
\hline 6.139 & 0.430 & & 11.947 & 0.246 & & 11.507 & 0.205 & \\
\hline 6.277 & 0.172 & & 12.233 & 0.444 & & 11.661 & 0.159 & \\
\hline 6.420 & 0.493 & & 12.313 & 0.248 & & 11.833 & 0.272 & \\
\hline 6.528 & 0.616 & & 12.388 & 1.408 & dimethyl ethanone & 11.924 & 1.230 & $\begin{array}{l}\text { dihydro indenol } \\
\mathrm{C}_{9} \mathrm{H}_{8} \mathrm{O}\end{array}$ \\
\hline 6.654 & 1.201 & $\begin{array}{l}\text { bicycle octane } \\
\text { methylene } \mathrm{C}_{9} \mathrm{H}_{14}\end{array}$ & 12.748 & 0.348 & phenyl $\mathrm{C}_{10} \mathrm{H}_{12} \mathrm{O}$ & 12.033 & 0.213 & \\
\hline 6.826 & 4.329 & $\begin{array}{l}\text { ethyl methyl } \\
\text { benzene } \mathrm{C}_{9} \mathrm{H}_{12}\end{array}$ & 12.868 & 1.169 & $\begin{array}{l}\text { methyl indanone } \\
\mathrm{C}_{10} \mathrm{H}_{10} \mathrm{O}\end{array}$ & 12.256 & 0.206 & \\
\hline 6.935 & 3.274 & $\begin{array}{l}\text { trimethyl } \\
\text { benzene } \mathrm{C}_{9} \mathrm{H}_{12}\end{array}$ & 12.977 & 0.283 & & 12.388 & 0.193 & \\
\hline 7.146 & 4.496 & $\begin{array}{l}\text { trimethyl } \\
\text { benzene } \mathrm{C}_{9} \mathrm{H}_{12}\end{array}$ & 13.155 & 0.479 & $\begin{array}{l}\text { di methyl indanone } \\
\mathrm{C}_{11} \mathrm{H}_{12} \mathrm{O}\end{array}$ & 12.754 & 0.234 & \\
\hline 7.421 & 6.293 & $\begin{array}{l}\text { ethyl methyl } \\
\text { benzene } \mathrm{C}_{9} \mathrm{H}_{10}\end{array}$ & 13.212 & 0.306 & & 12.880 & 0.492 & \\
\hline 7.610 & 0.155 & & 13.332 & 0.612 & di methyl indanone & 12.983 & 0.82 & $\begin{array}{l}\text { tetra methyl phenol } \\
\mathrm{C}_{10} \mathrm{H}_{14} \mathrm{O}\end{array}$ \\
\hline 7.696 & 0.67 & & 13.549 & 0.275 & & 13.046 & 0.125 & \\
\hline 7.879 & 4.175 & $\begin{array}{l}\text { methyl methoxy } \\
\text { benzene } \mathrm{C}_{8} \mathrm{H}_{10} \mathrm{O}\end{array}$ & 13.738 & 0.355 & & 13.395 & 0.466 & \\
\hline 8.113 & 2.218 & $\begin{array}{l}\text { trimethyl } \\
\text { benzene } \mathrm{C}_{9} \mathrm{H}_{12}\end{array}$ & 13.818 & 0.392 & & 13.463 & 0.796 & \\
\hline 8.268 & 1.936 & $\begin{array}{l}\text { methyl ethenel } \\
\text { benzene } \mathrm{C}_{9} \mathrm{H}_{10}\end{array}$ & 13.876 & 0.309 & & 13.658 & 0.655 & \\
\hline 8.611 & 1.861 & $\begin{array}{l}\text { methyl propenyl } \\
\text { benzene } \mathrm{C}_{10} \mathrm{H}_{12}\end{array}$ & 13.950 & 0.356 & & 13.744 & 0.784 & \\
\hline 8.794 & 2.325 & $\mathrm{C}_{10} \mathrm{H}_{12}$ & 14.202 & 0.325 & & 13.847 & 0.166 & \\
\hline 10.007 & 5.084 & & 14.345 & 0.266 & & 13.898 & 0.138 & \\
\hline 10.540 & 2.167 & $\begin{array}{l}\text { methyl buthenyl } \\
\text { benzene } \mathrm{C}_{11} \mathrm{H}_{12}\end{array}$ & 14.625 & 0.546 & $\begin{array}{l}\text { trimethyl butenyl } \\
\text { benzene } \mathrm{C}_{13} \mathrm{H}_{8}\end{array}$ & 14.076 & 0.195 & \\
\hline 12.748 & 1.793 & $\begin{array}{l}\text { cyclopentenyl } \\
\text { benzene } \mathrm{C}_{11} \mathrm{H}_{12}\end{array}$ & 14.717 & 0.600 & $\begin{array}{l}\text { dimethyl indole } \\
\mathrm{C}_{10} \mathrm{H}_{11} \mathrm{~N}\end{array}$ & 14.396 & 0.579 & \\
\hline 16.376 & 0.921 & $\begin{array}{l}\text { tetramethyl } \\
\text { naphthalene } \\
\mathrm{C}_{14} \mathrm{H}_{16}\end{array}$ & 14.803 & 0.691 & $\begin{array}{l}\text { Naphthalene } \\
\text { carbonitrile } \mathrm{C}_{11} \mathrm{H}_{7} \mathrm{~N}\end{array}$ & 14.482 & 0.304 & \\
\hline 17.280 & 0.710 & $\begin{array}{l}\text { dimethyl methyl } \\
\text { ethyl } \\
\text { naphthalene } \\
\mathrm{C}_{15} \mathrm{H}_{18}\end{array}$ & 14.906 & 0.411 & & 14.608 & 0.355 & \\
\hline 17.652 & 0.75 & $\begin{array}{l}\text { methyltridecene } \\
\mathrm{C}_{14} \mathrm{H}_{28}\end{array}$ & 15.071 & 0.356 & & 14.797 & 0.176 & \\
\hline 17.795 & 1.341 & & 15.306 & 0.409 & & 14.917 & 0.298 & \\
\hline 18.384 & 2.313 & $\begin{array}{l}\text { octadecene } \\
\mathrm{C}_{18} \mathrm{H}_{36}\end{array}$ & 15.449 & 0.532 & & 15.117 & 0.346 & \\
\hline 18.545 & 1.148 & & 15.535 & 0.409 & & 15.466 & 0.210 & \\
\hline 18.653 & 0.566 & & 15.838 & 0.277 & & 15.632 & 0.647 & \\
\hline 19.380 & 1.777 & $\begin{array}{l}\text { nonadecene } \\
\mathrm{C}_{19} \mathrm{H}_{40}\end{array}$ & 16.107 & 0.685 & & 15.758 & 0.197 & \\
\hline 20.336 & 1.437 & eicosane $\mathrm{C}_{20} \mathrm{H}_{42}$ & 16.239 & 0.338 & & 15.993 & 0.185 & \\
\hline 21.263 & 1.13 & $\begin{array}{l}\text { heneicosane } \\
\mathrm{C}_{21} \mathrm{H}_{44}\end{array}$ & 16.387 & 1.050 & $\begin{array}{l}\text { benzophenone } \\
\mathrm{C} 13 \mathrm{H} 10 \mathrm{O}\end{array}$ & 16.262 & 0.159 & \\
\hline 22.172 & 1.375 & & 16.491 & 0.348 & & 16.525 & 0.306 & \\
\hline 23.048 & 1.595 & & 17.000 & 0.239 & & 16.771 & 0.124 & $\begin{array}{l}\text { methylpropyl ester } \\
\mathrm{C}_{14} \mathrm{H}_{26} \mathrm{O}_{4}\end{array}$ \\
\hline 23.923 & 0.737 & docosane $\mathrm{C}_{22} \mathrm{H}_{46}$ & 17.469 & 0.267 & & 16.880 & 1.155 & hexane dioic acid \\
\hline
\end{tabular}




\begin{tabular}{|c|c|c|c|c|c|c|c|c|}
\hline 24.038 & 1.212 & & 18.173 & 0.403 & & 17.515 & 1.123 & $\begin{array}{l}\text { cyclotetradecane } \\
\mathrm{C}_{14} \mathrm{H}_{28}\end{array}$ \\
\hline 24.667 & 1.81 & tricosane $\mathrm{C}_{23} \mathrm{H}_{48}$ & 18.270 & 0.405 & & 17.595 & 0.516 & \\
\hline 25.457 & 1.31 & $\begin{array}{l}\text { tetracosane } \\
\mathrm{C}_{24} \mathrm{H}_{50}\end{array}$ & 18.608 & 0.466 & & 17.726 & 0.350 & \\
\hline 26.149 & 2.89 & $\begin{array}{l}\text { hexacosane } \\
\mathrm{C}_{26} \mathrm{H}_{54}\end{array}$ & 18.991 & 0.505 & hanthone $\mathrm{C} 13 \mathrm{H} 8 \mathrm{O} 2$ & 18.791 & 0.902 & carbozole $\mathrm{C}_{12} \mathrm{H}_{9} \mathrm{~N}$ \\
\hline 27.562 & 1.787 & & 20.130 & 0.792 & $\begin{array}{l}\text { antracenedion } \\
\mathrm{C} 14 \mathrm{H} 8 \mathrm{O} 2\end{array}$ & 18.917 & 0.548 & \\
\hline \multirow[t]{22}{*}{33.839} & 1.636 & $\begin{array}{l}\text { pentatri acontene } \\
\mathrm{C}_{35} \mathrm{H}_{70}\end{array}$ & 20.284 & 0.538 & & 19.569 & 0.421 & \\
\hline & & & 21.102 & 0.305 & & 19.781 & 0.262 & \\
\hline & & & 21.417 & 0.297 & & 19.855 & 0.326 & \\
\hline & & & 22.413 & 0.691 & $\begin{array}{l}\text { tetra thio } \\
\text { cyclododecane } \\
\text { C8H14S4 }\end{array}$ & 19.929 & 0.348 & \\
\hline & & & 22.550 & 0.274 & & 20.170 & 0.420 & \\
\hline & & & 22.716 & 2.169 & $\begin{array}{l}\text { dimethyl dimethoxy } \\
\text { benzo thiopyran } \\
\mathrm{C} 13 \mathrm{H} 16 \mathrm{O} 2 \mathrm{~S}\end{array}$ & 20.547 & 0.750 & \\
\hline & & & 22.899 & 1.189 & $\begin{array}{l}\text { methyl naptadecyl } \\
\text { keton } \mathrm{C} 19 \mathrm{H} 38 \mathrm{O}\end{array}$ & 20.645 & 0.152 & \\
\hline & & & 23.088 & 0.428 & & 20.845 & 0.273 & \\
\hline & & & 23.466 & 0.377 & & 21.680 & 0.235 & \\
\hline & & & 23.672 & 0.949 & $\begin{array}{l}\text { tetrahydrobenzene } \\
\text { C18H16 }\end{array}$ & 23.185 & 1.746 & $\begin{array}{l}\text { tienol abieta } \\
\mathrm{C}_{20} \mathrm{H}_{30} \mathrm{O}\end{array}$ \\
\hline & & & 23.986 & 0.530 & & 23.374 & 5.831 & $\begin{array}{l}\text { tienol abieta } \\
\mathrm{C}_{20} \mathrm{H}_{30} \mathrm{O}\end{array}$ \\
\hline & & & 24.444 & 0.507 & & 23.528 & 1.535 & $\begin{array}{l}\text { methyl indole } \\
\mathrm{C}_{13} \mathrm{H}_{11} \mathrm{NS}\end{array}$ \\
\hline & & & 24.536 & 0.498 & & 23.683 & 1.471 & $\begin{array}{l}\text { buthylphosponic } \\
\text { acid chlorophenyl } \\
\text { pentyl ester } \\
\mathrm{C}_{15} \mathrm{H}_{24} \mathrm{ClO}_{3} \mathrm{P} \\
\end{array}$ \\
\hline & & & 24.793 & 5.729 & $\begin{array}{l}\text { methyl dihydro } \\
\text { phenanthrenone cyclo } \\
\text { penta }\end{array}$ & 23.752 & 2.449 & $\begin{array}{l}\text { trimethyl hydroxy } \\
\text { phenanthrenone } \\
\mathrm{C}_{20} \mathrm{H}_{28} \mathrm{O}_{2}\end{array}$ \\
\hline & & & 24.885 & 1.650 & $\begin{array}{l}\text { ethylhexyl phthalate } \\
\mathrm{C}_{24} \mathrm{H}_{38} \mathrm{O}_{4}\end{array}$ & 23.912 & 1.492 & $\begin{array}{l}\text { trimethyl } \\
\text { dihydrochromenyle } \\
\text { phenol } \mathrm{C}_{18} \mathrm{H}_{20} \mathrm{O}_{2}\end{array}$ \\
\hline & & & 25.434 & 3.772 & anthracenedione acthyl & 24.267 & 6.450 & $\begin{array}{l}\text { trimethyl dihydro } \\
\text { phenol }\end{array}$ \\
\hline & & & 25.651 & 0.567 & $\begin{array}{l}\text { methoxy hydroxy } \\
\mathrm{C}_{17} \mathrm{H}_{12} \mathrm{O}_{5}\end{array}$ & 24.455 & 0.328 & $\begin{array}{l}\text { benzopyranyl } \\
\mathrm{C}_{18} \mathrm{H}_{20} \mathrm{O}_{2}\end{array}$ \\
\hline & & & 25.806 & 0.607 & & 24.581 & 4.148 & $\begin{array}{l}\text { methyl } \\
\text { phenylanthracene } \\
\mathrm{C}_{21} \mathrm{H}_{16}\end{array}$ \\
\hline & & & 26.063 & 1.101 & $\begin{array}{l}\text { octahydrobenzo } \\
\text { pyrene } \mathrm{C}_{20} \mathrm{H}_{20}\end{array}$ & 24.753 & 0.423 & \\
\hline & & & 26.309 & 0.237 & & 25.131 & 2.601 & $\begin{array}{l}\text { trimethyl } \\
\text { anthracenyl silane } \\
\mathrm{C}_{17} \mathrm{H}_{18} \mathrm{Si}\end{array}$ \\
\hline & & & 26.384 & 0.327 & & 25.205 & 0.999 & $\begin{array}{l}\text { methyl trimethyl } \\
\text { benzopyranone } \\
\mathrm{C}_{13} \mathrm{H}_{14} \mathrm{O}_{5}\end{array}$ \\
\hline & & & 26.430 & 0.275 & & 25.400 & 1.075 & $\begin{array}{l}\text { methyl diphenyl } \\
\text { imidazolinone } \\
\mathrm{C}_{16} \mathrm{H}_{14} \mathrm{~N}_{2} \mathrm{O}\end{array}$ \\
\hline
\end{tabular}




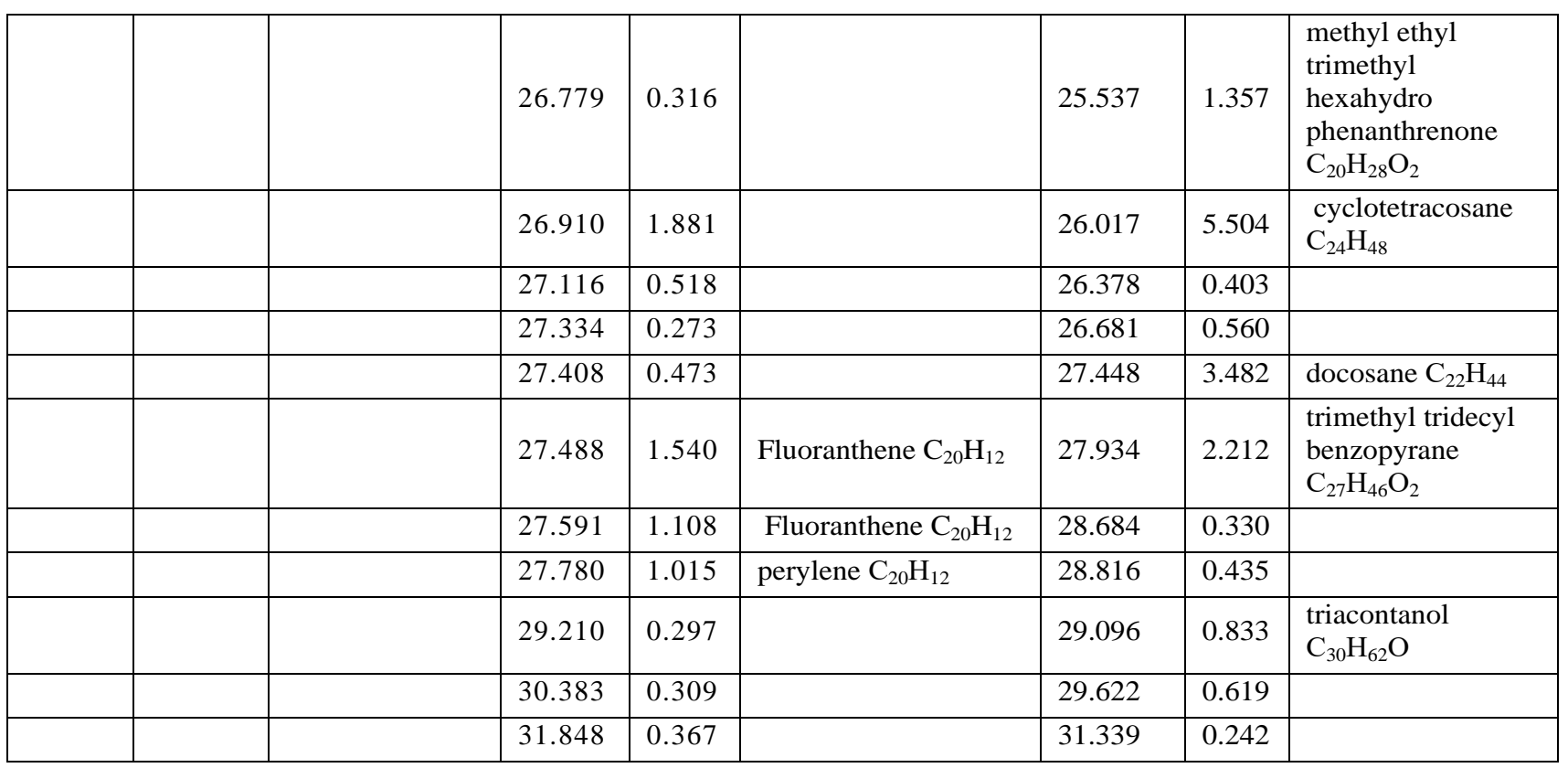

\section{References}

[1] B. Purevsuren, Coal is the main source of energy in Mongolia, in: Abstracts of papers, Second Korean and Mongolian Energy Conference, Yonsei University, Seoul, Korea, 2007.

[2] B. Purevsuren, Ya. Davaajav, R. Erdenechimeg, Investigation on largest coal deposits in Mongolia, Monograph, Toonotprint, 2010.

[3] B.Avid et al., An exploratory investigation on the performance of Shivee-Ovoo coal and Khoot oil shale from Mongolia, Fuel. 83(7-8) (2004) 1105-1111.

[4] B.Avid et al., Pyrolysis and TG analysis of the Shivee Ovoo coal Mongolia, Journal of Thermal Analysis and Calorimetry. 68(3) (2002) 877-885. 